\title{
Student employability examined from academic achievement and self-concept
}

Fatwa Tentama, Muhamad Hasan Abdillah

Master of Psychology, Universitas Ahmad Dahlan, Indonesia

\begin{tabular}{|c|c|}
\hline Article Info & ABSTRACT \\
\hline Article history: & \multirow{9}{*}{$\begin{array}{l}\text { Employability is a problem that often arises in its relation to job-seeking, } \\
\text { where low employability has become an obstacle for individuals entering the } \\
\text { workforce. Factors believed to influence levels of employability are } \\
\text { academic achievements and self-concept. This study aimed to determine the } \\
\text { relationship between academic achievement and self-concept with student } \\
\text { employability. The subjects in this study were } 85 \text { students who were obtained } \\
\text { through cluster random sampling. The research method used is a quantitative } \\
\text { method, utilizing scales and report card scores as data collection tools. The } \\
\text { scale used is scale of employability and self-concept. The data analysis used } \\
\text { in this study is multiple linear regression analysis. The results of the data } \\
\text { analysis showed significant relationship between academic achievement and } \\
\text { self-concept with employability. }\end{array}$} \\
\hline Received Feb 5, 2019 & \\
\hline Revised Apr 14, 2019 & \\
\hline Accepted Apr 29, 2019 & \\
\hline Keywords: & \\
\hline Academic achievement & \\
\hline Employability & \\
\hline Self-concept & \\
\hline Student & \\
\hline
\end{tabular}

Copyright (C) 2019 Institute of Advanced Engineering and Science. All rights reserved.

\section{Corresponding Author:}

Fatwa Tentama,

Faculty of Psychology, Universitas Ahmad Dahlan,

Kapas street 9, Semaki, Umbulharjo, Yogyakarta.

Email: fatwa.tentama@psy.uad.ac.id

\section{INTRODUCTION}

Vocational High School is an educational institution that prepares students for a career in a particular job or technical field [1]. At this level of education, students are braced with skills that enable them to enter the workforce upon graduation [2]. Vocational high schools aim to provide a labor market at the subprofessional level [3]. In addition to providing labor, Hirvonen [4] added that vocational high schools also prepare graduates for entrepreneurship. According to the Director of Vocational Education, Mustaghfirin Amin, there is currently increasing interest towards vocational high schools by junior high school graduates. Evidently, since 2011, the number of vocational students has increased to the point of exceeding high school students. In 2015 , the number of vocational students reached 4.4 million, while the number for high school students is 4.3 million [5].

Technically, vocational high school graduates should have work employability as they have been equipped with skills that urge them towards work independence and readiness, hence vocational high school is seen as a solution to reduce unemployment. However, the reality in the field shows that vocational high school graduates are one of the most significant contributors to open unemployment in Indonesia. Data from the Central Statistics Agency (BPS) in 2017 showed that the most substantial amount of open unemployment is dominated by vocational high school graduates [6]. The percentage of unemployed graduates from vocational high schools reached $9.27 \%$, while for high school graduates the percentage was $7.03 \%$, followed by $5.36 \%$ for junior high school graduates, $6.35 \%$ for Diploma III (D3) graduates, and $4.98 \%$ for University graduates. This shows that vocational high school graduates who are considered ready-to-use workers and easily absorbed by the job market do not have the employability to work. Based on the results of research conducted by Ronnås dan Shamchiyeva [7], one of the factors that cause unemployment of vocational high school graduates is low employability. 
An example of this employability phenomenon in vocational high schools is in Vocational High School Koperasi Yogyakarta. Based on the results of the preliminary interviews conducted on April 13, 2018, with several students from the accounting and marketing majors in class XI of Vocational High School Koperasi Yogyakarta, students have yet to figure out the profession or occupation they wanted to choose upon graduation. Furthermore, the reason students entered Vocational High School Koperasi Yogyakarta was due to their parents' choices and/or motivated by their peers.

Interviews conducted on April 17-20, 2018 with several students from accounting and marketing majors found that the most dominant factors in influencing employability are factors of academic achievement and self-concept. One student in class XI majoring in accounting stated, "after graduation [I have] no illustration of [what work will be like] and what profession I should pursue." This is supported by the results of research conducted by Pan and Lee [8], who found that low academic achievement reflects low employability of vocational high school students. Similarly, according to Jackson [9] results from low academic achievement is low employability.

High academic achievement is seen as a reasonable provision for individuals entering the workforce, as those with exceptional academic achievements tend to have a higher concentration, more (unique) knowledge and expertise in the field [10]. According to Dacre, Pool, and Sewell [11] individuals with high levels of academic achievement will motivate themselves to have earn employability by developing their potential skills and knowledge. Findings of research conducted by Surridge [12] shows that individuals with low academic achievement tend to be hesitant in choosing and determining their jobs. This is in line with the opinion of Omar, Bakar, and Mat Rashid [13] who revealed that low academic achievement in the areas of knowledge and skills could hinder individuals' opportunity to obtain jobs.

In addition to academic achievement, self-concept is a factor that is also believed to have the ability to enhance the employability of students in vocational schools [14]. According to the findings of McArdle, Waters, Briscoe, and Hall [15], concept plays a vital role in increasing employability. Meanwhile, according to Kim, Kim, and Lee [16], a strong positive self-concept within a specific framework can increase an individual's employability. To increase an individual's employability, one of the factors that need to be considered is positive individual self-concept [17].

An example of the self-concept phenomenon can be seen from students of class XI of Vocational High School Koperasi Yogyakarta, where an interview on April 20, 2018, with the teacher in charge of student affairs shows that when the school intended to implement a full day school policy aiming to increase the proportion of hours of practice, many students disagreed. Students also often come late and miss school. A class XI marketing student said "when the [morning] bell rings, the school gate is then closed, [if] we are late the security guard does not open the gate, so we go home. Simply with this policy of closing the gate after the first bell rings, there are already many students who come late or do not go to school, what will happen if the full day school program is implemented".

Self-concept molds individuals to become more confident in their ability to work, have a stable career identity, and define themselves more broadly regarding careers [18]. According to Coetzee and Schreuder [19], self-concept provides clarity regarding an individual's career values, motives, interests, and needs. Although there is objectivity concerning how an individual's skills, knowledge, and experience may improve employability, low self-concept is believed to have an impact on low employability [16]. Negative self-concept can have an impact on individual behavior, unclear career goals, low life meaning, and low individual motivation [20]. This study aimed to empirically examine the relationship between academic achievement and self-concept with employability of students at Vocational High School Koperasi Yogyakarta. Employability is a significant problem which is one of the causes of unemployment.

\section{RESEARCH METHOD}

The subjects in this study were 85 students of class XI in Vocational High School Koperasi Yogyakarta who come from 3 different classes, namely: accounting class, marketing class, and visual communication design class. The sampling technique used in this study was cluster random sampling technique.

Two data collection tools were used in this study, namely scales as well secondary data in the form of scores from the student's practical courses. The employability and self-concept scale takes form of a likert scale model, while for academic achievement, the data collection tool used are the scores from the students' practical courses. Employability is studied by using the employability scale which refers to aspects of employability according to Fugate, Kinicki, and Ashforth [21], namely career identity, personal adaptability, as well as social and human capital. Academic achievement is obtained from a comprehensive assessment starting from the input, process, and output of learning which includes cognitive, affective, and psychometric

Int. J. Eval. \& Res. Educ. Vol. 8, No. 2, June 2019: 243 - 248 
domains [22]. Self-concept is studied using the self-concept scale which refers to aspects of self-concept according to Berzonsky [23], namely physical, psychological, social, and moral aspects.

The employability scale which was tried out on 38 subjects, resulted in a reliability coefficient of 0.886 . The corrected item-total correlation shifted from 0.348 to 0.675 . 26 items were found to be valid and reliable hence used in the study. The scale of self-concept which was tried out on 38 subjects resulted in a reliability coefficient of 0.862 . The corrected item-total correlation index shifted from 0.314 to 0.664 . 18 items were found to be valid and reliable hence used in the study.

The data was analysed using parametric statistical tests. Data analysis were performed using SPSS 17.0 for Windows, through multiple regression technique, which is a statistical analysis technique to determine the relationship of two independent variables (academic achievement and self-concept) with one dependent variable (employability).

\section{RESULTS AND DISCUSSION}

\subsection{Normality test}

Based on Table 1, the results of the normality testing showed normal distribution on employability variables with a K-SZ score coefficient $=0.992$ and $p=0.228$; for the academic achievement variable the KSZ score coefficient $=0.925$ and $p=0.326$; for the self-concept variable with a coefficient of K-SZ score $=$ 0.868 and $p=0.438$. This being said each data set is normally distributed, meaning that there are no difference between the distribution of sample scores and population scores - in other words the sample used in this study is able to represent the population.

Table 1. Normality test

\begin{tabular}{lccc}
\hline \multicolumn{1}{c}{ Variable } & KS-Z & Sig & Interpretation \\
\hline Employability & 0.992 & 0.228 & Normal \\
Academic Achievement & 0.925 & 0.326 & Normal \\
Self-concept & 0.868 & 0.438 & Normal \\
\hline
\end{tabular}

\subsection{Linearity test}

Based on Table 2, from the results of linearity test an $F$ was obtained on academic achievement towards employability with a score of 15.428 and a significance level $(p)$ of 0.001 which means that the data is linear, in other words, there is a line that connects academic achievement towards employability. From the results of the linearity test of self-concept towards employability, an F score was obtained with a linearity of 43.229 and a significance level (p) of 0.000 which means that the data is linear or that there is a straight line that connects between self-concept and employability.

Table 2. Linearity test

\begin{tabular}{cccc}
\multicolumn{4}{c}{ Table 2. Linearity test } \\
Variable & F Linearity & Sig & Interpretation \\
\hline Academic Achievement with Employability & 15.428 & 0.001 & Linear \\
Self-concept with Employability & 43.229 & 0.000 & Linear \\
\hline
\end{tabular}

\subsection{Multicollinearity test}

Based on Table 3, the results of the multicollinearity test showed that academic achievement and self-concept had a VIF value $=1.192$ and tolerance $=0.839$, therefore there was no multicollinearity between academic achievement and self-concept.

Table 3. Multicollinearity test

\begin{tabular}{lccc}
\hline \multicolumn{1}{c}{ Variable } & Tolerance & VIF & Interpretation \\
\hline Academic Achievement & 0.839 & 1.192 & There is no multicollinearity \\
Self-concept & 0.839 & 1.192 & There is no multicollinearity \\
\hline
\end{tabular}

\subsection{Multiple linear regression test}

Based on Table 4, the results of the regression analysis of academic achievement and self-concept towards employability obtained a correlation coefficient $(\mathrm{R})$ of 0.594 with a significance level $(p)$ of 0.000 which indicates that there is a highly significant positive relationship between academic achievement and 
self-concept towards employability. The contribution of the influence of academic achievement and selfconcept towards employability is indicated by the value of $\mathrm{R}$ Square $=0.353$, meaning that the influence of academic achievement and self-concept contributes $35.3 \%$ and the remaining $64.7 \%$ is influenced by other factors beyond the variables studied.

Table 4. Multiple linear regression test

\begin{tabular}{ccccc}
\hline Variable & $\mathrm{R}$ & $\mathrm{R}$ Square & Sig & Interpretation \\
\hline Academic Achievement and Self-concept towards Employability & 0.594 & 0.353 & 0.000 & There is a relationship \\
\hline
\end{tabular}

\subsection{Analysis of relationship between variables}

Based on Table 5 about the results of the regression analysis, a zero-order correlation was obtained between academic achievement with employability with as score of 0.367 and a significance level $(p)$ of $0.000(p<0.01)$, which means that there is a very significant positive relationship between academic achievement wand employability. The results of the regression analysis between self concept and employability obtained a zero-order correlation of 0.575 with a significance level $(p)$ of $0.000 \quad(p<0.01)$ which means that there is a very significant positive relationship between self-concept and employability.

Table 5. Analysis of relationship between variables

\begin{tabular}{cccc}
\hline Variable & Zero-order & Sig & Interpretation \\
\hline Academic Achievement and Employability & 0.367 & 0.000 & There is a very significant positive relationship \\
Self-concept and Employability & 0.575 & 0.000 & There is a very significant positive relationship \\
\hline
\end{tabular}

Academic achievement and self-concept are factors that perform an substantial role in the process of forming employability, if individuals possess high academic achievement and self-concept then employability tend to be high, vice versa, if individuals have low academic achievement and self-concept, employability tend to be low. The results of this study are in line with the results of previous studies, such as the results of Pan and Lee's research [8], which found that low academic achievement can lead to low employability of vocational high school students. According to Jackson [9], low employability is caused by low academic achievement. This is in line with the research findings of Pinto and Ramalheira [24], which show that learning achievement is related to employability.

According to Pan and Lee [8], high academic achievement will provide confidence and motivation in order for individuals to confront various challenge they meet in finding a job. In addition, according to Pinto and Ramalheira [24], individuals who have high academic achievements are better prepared to find work due to mastery of their educational and vocational training materials. The results of a research conducted by McKinney, Carlson, Mecham, D'Angelo, and Connerley [25] show that low academic achievement will give individuals fewer job choices and a limit to their range of salary. Further research also found that low academic achievement make the selection process harder [8]. This is supported by the results of Pinto and Ramalheira's research [24] which found that low academic achievement lead individuals to obtain jobs that sometimes do not match their desires, meaning that there are fewer choices of work they can have.

Individuals who are able to apply knowledge and understanding of their fields of expertise will find it easier to get a job, as this ability will increase the individual's confidence in getting a job. The ability to apply knowledge and understanding may also shape a goal to obtain a job geared to the type of work the individual desires, hence more targeted goals will bring affirmative expectations for the individual. The relationship between academic achievement and employability can also be shown when individuals have the readiness to work that in turn enables individuals to believe they are able to adapt to the novel environment. Readiness to work in a novel environment will also increase individuals' ability to control themselves, because new environments call individuals to learn to accept values that are different from the value system they have as well as a certain value system that has never been studied before.

Good adaptability will allow individuals to acquire more friends and formal job search networks. The skills possessed by individuals in their fields when combined with good adaptability will enable individuals to acquire jobs more easily because they are able to create new patterns of movement in accordance with the situation they are facing and are also able to utilize the job search networks (friends) as well as more formal networks (organizations) through their knowledge.

Another factor that can improve employability is self-concept [14]. According to Wu, Tsai, and Chen [26], their research found that self-concept is related to employability. This is similar to findings of

Int. J. Eval. \& Res. Educ. Vol. 8, No. 2, June 2019: 243 - 248 
Kim, Kim and Lee's research [16] which shows that low self-concept can lead to low employability. Selfconcept is an important factor in the formation of employability within the school environment [14]. According to Calhoun and Acocella [27] positive self-concept will increase individual employability, as this positivity enables them to take a positive stance towards everything they face, better at appreciating themselves and see viable positive steps they can take to obtain a job. Meanwhile according to $\mathrm{Wu}$, Tsai, and Chen [26], individuals who have a high self-concept will have a relatively clear and concrete vocational orientation; meaning that individuals will be more confident about their future job choices.

Self-concept is an important part of personality that functions as a determinant of individuals' attitude and behaviour [28]. Individuals who have a positive self-concept will feel confident and take a positive stance about everything they face, see viable positive steps that can be taken towards their success [27]. Meanwhile Chaplin [29] stated that individuals who have a positive self-concept will influence how they decide their attitudes and behaviour.

A negative self concept will lead an individual to judge that he is never good enough, so that whatever he achieves is worthless in comparison to what others have obtained [27]. Stuart and Sundeen [28] state that individuals who have a negative self-concept will see themselves as incapable and helpless, which in turn influences their attitude in trying or working. According to Hadley, Hair, and Moore [30], individuals who have a negative self-concept will easily be jealous of what others have, less control over their own emotions, and consider themselves inferior leading to lack of confidence or hesitation to try new things.

Students who have positive image of their physical condition are believed to have an easier time in getting a job, because they have confidence in their physical strengths. The ability to appreciate everything an individual has by balancing his/her mind and attitude will hone good self-control skills. Individuals with good self control will have an easier time trying to adapt to the new environment in order to acquire a job.

Individuals who are capable in playing a role in their social sphere will find it easier to acquire friends who can help in finding a job search network. The probability in obtaining a job becomes higher by utilizing such job search network. The values and principles possessed by individuals will form a purpose that is more focused in developing their potential. Individuals with more directed goals are believed to find it easier in obtaining a job compared to individuals who do not have clear goals. These objectives will provide meaning and direction for the individual to achieve something related to work.

\section{CONCLUSION}

Employability is a significant problem which is one of the causes of unemployment. Factors believed to influence levels of employability are academic achievements and self-concept. The current study concluded that there is a positive relationship between academic achievement and self-concept with employability in students of Vocational High School Koperasi Yogyakarta. That means the higher academic achievement and self-concept, the higher employability among students and vice versa.

\section{ACKNOWLEDGEMENTS}

The authors would like to express their sincere gratitude to the Faculty of Psychology Universitas Ahmad Dahlan and Vocational High School Koperasi Yogyakarta for the technical help provided during this study. The authors would also like to thank students who have participated in this study, as well as teachers, school-administrators, and other individuals for their efforts, assistance, and involvement in this research effort.

\section{REFERENCES}

[1] Gibson, RL, Mitchell, MH, "Introduction to counseling and guidance," New York, Macmillan Publisher, 2011.

[2] Behroozi, M., "survey about the function of technical and vocational education: An empirical study in Bushehr City," Procedia-Social and Behavioral Sciences, vol. 143, pp. 265-269, 2014.

[3] Rahman, AA, Hanafi, MN, Mukhtar, IM, Ahmad, J., "Assessment practices for competency based education and training in vocational college, Malaysia," Procedia-Social and Behavioral Sciences, vol. 112, pp. 1070-1076, 2014.

[4] Hirvonen, A., "Business model development in newspaper publishing industry, the effect of e-reading a case study," Helsinki, Aalto University, 2011.

[5] Amin, N., "The number of SMK students defeats high school, this is the data (in Bahasa)," 2015. [Online]. Available: jpnn, https://www.jpnn.com/news/jumlah-siswa-smk-kalahkan-sma-ini-datanya.

[6] Kusuma, H., " Unemployment in Indonesia is dominated by SMK graduates (in Bahasa)," [Online]. Available: finance.detik https: //finance.detik.com/berita-ekonomi-bisnis/3493153/pengangguran-di-ri-didominasi-lulusansmk., 2017.

[7] Ronnås, P., Shamchiyeva, L., Employment diagnostic analysis: Maluku, Indonesia, Geneva: International Labour Organization, 2011. 
[8] Pan, YJ, Lee, LS, "Academic performance and perceived employability of graduate students in business and management: An analysis of nationwide graduate destination survey," Procedia-Social and Behavioral Sciences, vol. 25, pp. 91-103, 2011.

[9] Jackson, D., "Self-assessment of employability skill outcomes among undergraduates and alignment with academic ratings," Assessment \& Evaluation in Higher Education, vol. 39(1), pp. 53-72, 2014.

[10] Omar, NH, Manaf, AA, Mohd, RH, Kassim, AC., Aziz, KA, "Graduates' employability skills based on current job demand through electronic advertisement," Asian Social Science, vol. 8(9), pp. 103-110, 2012.

[11] Dacre Pool, L., Sewell, P, "The key to employability: Developing a practical model of graduate employability," Education Training, vol. 49(4), pp. 277-289, 2007.

[12] Surridge, I., "Accounting and finance degrees: Is the academic performance of placement students better?," Accounting Education: An International Journal, vol. 18(4-5), pp. 471-485, 2009.

[13] Omar, MK., Bakar, AR., Mat Rashid, A., "Employability skill acquisition among malaysian community college students," Journal of Social Sciences, vol. 8(3), pp. 472-478, 2012.

[14] Dania, J., Bakar, AR., Mohamed, S., "Factors influencing the acquisition of employability skills by students of selected Technical Secondary School in Malaysia," International Education Studies, vol. 7(2), pp. 117-124, 2014.

[15] McArdle, S., Waters, L., Briscoe, JP, Hall, DT., "Employability during unemployment: Adaptability, career identity and human and social capital," Journal of Vocational Behavior, vol. 71(2), pp. 247-264, 2007.

[16] Kim, S., Kim, H., Lee, J., "Employee self-concepts, voluntary learning behavior, and perceived employability," Journal of Managerial Psychology, vol. 30(3), pp. 264-279, 2015.

[17] Pierce, JL, Gardner, DG, "Self-esteem within the work and organizational context: a review of the organizationbased self-esteem literature," Journal of Management, vol. 30(5), pp. 591-622, 2004.

[18] Shaffer, D., Developmental psychology: Childhood and adolescence, Belmont: Wadsworth Thomson Learning, 2002.

[19] Coetzee, M., Schreuder, D., "The relation between career anchors, emotional intelligence and employability satisfaction among workers in the service industry," Southern African Business Review, vol. 5(3), pp. 76-97, 2011.

[20] Oyserman, D., Bybee, D., Terry, K., Hart-Johnson, T., "Possible selves as roadmaps," Journal of Research in Personality, vol. 38, 130-49, 2004.

[21] Fugate, M., Kinicki, AJ, Ashforth, BE, "Employability: A psycho-social construct, its dimensions, and applications," Journal of Vocational Behavior, vol. 65(1), pp. 14-38, 2004.

[22] Azwar, S., Tes prestasi: Fungsi dan pengembangan pengukuran prestasi belajar, Yogyakarta: Pustaka Pelajar, 2012.

[23] Berzonsky, Moral development child, USA: The MacMillan Psychology References Series, 2001.

[24] Pinto, LH, Ramalheira, DC, "Perceived employability of business graduates: The effect of academic performance and extracurricular activities," Journal of Vocational Behavior, vol. 99, pp. 165-178, 2017.

[25] McKinney, AP., Carlson, KD, Mecham, RL, D'Angelo, NC, Connerley, ML, "Recruiters' use of GPA in initial screening decisions: Higher GPAs don't always make the cut," Personnel Psychology, vol. 56(4), pp. 823-845, 2003.

[26] Wu, YL, Tsai, YL, Chen, CW., "Examining the experiences of career guidance, vocational self-concept, and self-perceived employability among science education majors in Taiwan," Journal of Baltic Science Education, vol. 13(2), pp. 182-190, 2014.

[27] Calhoun, JF, Acocella, JR., Psychology of assessment and human relationship, New York: McGraw Hill, 2004.

[28] Stuart, GW, Sundeen, Principles and practice of psychiatric nursing, Louis: Mosby, 2006.

[29] Chaplin, DD., Empowerment zones and e-rate application rates, Washington: Ther Service, 2006.

[30] Hadley, AM., Hair, EC., Moore, KA, "Assessing what kids think about themselves: A guide to adolescent selfconcept for out of school time program practitioners," Research to Results Child Trends, vol 32, pp. 1-6, 2008.

\section{BIOGRAPHIES OF AUTHORS}

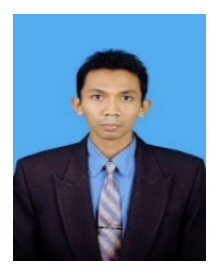

Fatwa Tentama was born on October 1, 1984 in Yogyakarta. Working as a lecturer at the Faculty of Psychology at Ahmad Dahlan University, Yogyakarta. His scientific focus and research is industrial psychology and educational psychology.

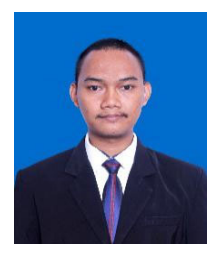

Muhamad Hasan Abdillah is a student at Master of Psychology, Universitas Ahmad Dahlan, Yogyakarta. At present his concentration of scientific fields is industrial psychology and educational psychology.

Int. J. Eval. \& Res. Educ. Vol. 8, No. 2, June 2019: 243 - 248 